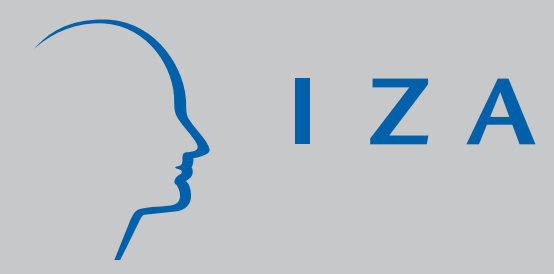

IZA DP No. 2552

Choice of Fields of Study of Canadian University Graduates:

The Role of Gender and their Parents' Education

Brahim Boudarbat

Claude Montmarquette

J anuary 2007 


\title{
Choice of Fields of Study of Canadian University Graduates: The Role of Gender and their Parents' Education
}

\author{
Brahim Boudarbat \\ Université de Montréal, \\ CIRANO and IZA \\ Claude Montmarquette \\ Université de Montréal and CIRANO
}

Discussion Paper No. 2552

January 2007

IZA

P.O. Box 7240

53072 Bonn

Germany

Phone: +49-228-3894-0

Fax: +49-228-3894-180

E-mail: iza@iza.org

\begin{abstract}
Any opinions expressed here are those of the author(s) and not those of the institute. Research disseminated by IZA may include views on policy, but the institute itself takes no institutional policy positions.
\end{abstract}

The Institute for the Study of Labor (IZA) in Bonn is a local and virtual international research center and a place of communication between science, politics and business. IZA is an independent nonprofit company supported by Deutsche Post World Net. The center is associated with the University of Bonn and offers a stimulating research environment through its research networks, research support, and visitors and doctoral programs. IZA engages in (i) original and internationally competitive research in all fields of labor economics, (ii) development of policy concepts, and (iii) dissemination of research results and concepts to the interested public.

IZA Discussion Papers often represent preliminary work and are circulated to encourage discussion. Citation of such a paper should account for its provisional character. A revised version may be available directly from the author. 


\section{ABSTRACT \\ Choice of Fields of Study of Canadian University Graduates: The Role of Gender and their Parents' Education*}

This paper examines the determinants of the choice of field of study by university students using data from the Canadian National Graduate Survey. The sample of 18,708 graduates holding a Bachelor degree is interesting in itself knowing that these students completed their study and thus represent a pool of high quality individuals. What impact expected postgraduation lifetime earnings have in choosing their field of study respectively to their non pecuniary preferences? Are these individuals less or more influenced by monetary incentives on their decision than was found in previous literature with samples of university students not all completing their studies successfully? Unlike existing studies, we account for the probability that students will be able to find employment related to their field of study when evaluating lifetime earnings after graduation. The parameters that drive students' choices of fields of study are estimated using a mixed multinomial logit model applied to seven broadly defined fields. Results indicate that the weight put by a student on initial earnings and earnings' rate of growth earnings depends upon the education level of the parent of the same gender. Surprisingly, lifetime earnings have no statistically significant impact when the parent of the same gender as the student has a university education. Results show that men are, in general, more sensitive than women to initial income variations, whilst women are more sensitive than men to the earnings' rate of growth variations. Marital status, enrolment status and the vocation identified with each field of study are influential factors in students' choices. From a policy perspective, a substantial increase in lifetime earnings, while all other factors remain constant, would be necessary to draw students into fields of study they are not inclined to choose initially.

JEL Classification: J24, C35

Keywords: Canada, university fields of study, expected lifetime earnings, mixed multinomial logit model, parents' education

Corresponding author:

Brahim Boudarbat

School of Industrial Relations

University of Montreal

C.P. 6128

Succursale Centre-ville

Montréal (Québec) H3C 3J7

Canada

E-mail: brahim.boudarbat@umontreal.ca

\footnotetext{
* The authors are grateful for valuable comments and suggestions from Daniel Boothby, Craig Riddell, Daniel Parent and numerous participants at international conferences and seminars. Research support from HRSDC-IC-SSHRC Skills Research Initiative is gratefully acknowledged.
} 


\section{Introduction}

University education has expanded to a remarkable extent in Canada. The proportion of the population aged 25 to 64 years (the working-age population) with a degree, certificate, or diploma from a university rose from $12.9 \%$ to $16.9 \%$ between 1981 and 1991, and then to $22.6 \%$ in 2001 . Within this age group, the percentage of individuals with a bachelor's degree nearly doubled during the same period, from $6.7 \%$ in 1981 to $12.8 \%$ in 2001 (Canadian census data). Furthermore, with $22 \%$ of the working-age population with a university degree in 2003, Canada ranks fourth among OECD nations with the Netherlands compared to $29 \%$ in the United States and Norway and $25 \%$ in Denmark (Education at a Glance 2005, OECD). If education is to continue to function as an engine of the country's socio-economic development, it is important for education policy in Canada to grasp individuals' university-related decisions, and their interaction with labour market conditions. With an aging population and many baby-boomers about to withdraw from the labour markets, there are concerns that certain fields of education might be ignored by women in particular, thus creating a shortage of skilled workers. Effective policies to influence individual decisions in their choice of fields of study must be related to the parameters that drive those decisions. Borghans and Groot (1999) assert that affirmative action programs that force employers to hire women in positions usually occupied by men are ineffectual, since they do not account for the fact that the educational segregation of the labour force cannot be reversed overnight. Effective

reverse discrimination programs are those that seek to rectify this segregation. However, this approach presupposes that the root of the educational segregation is not discrimination, but rather a consequence of the theory of human capital.

The basic principle of human capital theory is that individuals should keep investing in schooling as long as marginal benefits exceed marginal costs. A large number of empirical studies support this position, demonstrating that high levels of education are associated with high income 
levels (see Card, 1999, for a recent review). Empirical evidence strongly supports the view that investments in schooling yield positive pecuniary returns. However, relatively fewer studies have addressed the issue of choice of field of study for a given education level (horizontal choice) rather the choice of number of years of education (vertical choice).

In this study we will examine the process by which students in Canadian universities select a field of study. Specifically, we are interested in students' sensitivity to the expected lifetime income associated with each field of study when they make this decision. Although they do not account for the selection process, Boothby (1999) and Finnie (1999) show that wage gaps between university majors in Canada are substantial. Several existing studies have shown that economic factors are determinants in the choice of a field of study by students. Berger (1988) argued that students are more strongly influenced by lifetime income than by initial income. Polachek (1978) has suggested that expectations regarding the extent of future labour-force participation also play a role in this choice. Individuals planning intermittent participation in the labour force avoid fields (such as the sciences) requiring a high level of on-the-job training. Blakemore and Low (1984) proposed a similar argument, postulating that young women who expect to drop out of the labour force to have children tend to select disciplines that are less prone to atrophy or obsolescence. Paglin and Rufolo (1990) and, more recently, Arcidiacono (2004) demonstrated that quantitative abilities are among the most important factors in the choice of field of study and the labour market outcomes. In Montmarquette, Cannings and Mahseredjian (2002), expected income in a particular field of study depends on the perceived probability of success in that field. The authors also found differences in the impact of expected earnings on the choice of discipline by gender and race. Women are less influenced by this variable than men. This is also true of "non-white" versus "white" students. Thomas and Montmarquette (2005) state that differences between men's and women's educational choices are more clearly delineated in terms of field of study than in the level 
of education. Finally, results for the impact of male-female income differentials are supported by the Boudarbat's (2004) study of community college students in Canada (Cégeps in Quebec). In addition, Boudarbat showed that youths having acquired work experience before attending college put more weight on earnings in their decisions.

Our study use data from the National Graduate Survey (NGS) for Canadian public postsecondary institutions, for three cohorts: 1986 (6,662 graduates), 1990 (6,787 graduates), and 1995 (5,259 graduates). Data from different cohorts allow the demand for various fields to react (adjustment) not only to interdisciplinary income gaps, but also to the intertemporal evolution of incomes within disciplines. The sample of 18,708 graduates holding a Bachelor degree is interesting in itself knowing that these students completed their study. In previous studies, not all students have obtained their diploma.

For each field of study, a key factor that may affect expected income, and one which has been ignored in existing studies, is whether the job to be held after graduation will be linked to the field of study. For all fields, graduates who have jobs that correspond to their studies earn more than those who don't (Boothby, 1999). Thus, a contribution of our study is accounting for the probability that students will be able to find employment in their fields when determining the expected lifetime income in each major.

A major obstacle that arises with this kind of study is that individual-specific rates of returns to studies are plagued by a fundamental selection problem. The problem is that earnings are generally only observed after the schooling investment has been completed. Since earnings before schooling is completed are generally missing, the earnings gain from each field of study choice cannot be measured directly. Willis and Rosen (1979), as well as several subsequent studies, suggest using income estimates corrected for selectivity bias to predict the income associated with each field of study for all students. However, the reliability of this econometric technique is 
critically dependent on the availability of instruments that explain students' choices without affecting the returns to fields of study. We opt for a more practicable measure of income that is available to students when they are making their choices. In our model, 1990 graduates base their decisions on income data for the preceding NGS cohort, i.e. the class of 1986. Similarly, 1995 graduates refer to their predecessors, the class of 1990. Practically, this means that the coefficients used to predict incomes of the persons in a given cohort are estimated from data for the preceding cohort. The benefit of this approach is that the coefficients in question are independent of the sample for which we are analysing the decision process.

Along with the expected economic return influencing the choice of field study, preference, information and family socio-economic background can also play an important role. Thus, we pay special attention to the relationship between parents' education and students' choices of fields of study. Drolet (2005) and others argue that the impact of parents' education on attending university appears to be more important than the impact of family income.

In Section II, we present a descriptive analysis of the NGS data. The econometric approach is presented in Section III, with the empirical results discussed in Section IV. In Section V, we conclude.

\section{Data and Descriptive Analysis}

The National Graduate Survey (NGS) for Canadian public post-secondary institutions conducted every five years, examines graduates' access to jobs and working conditions, among other issues. Each cohort is canvassed twice: two and five years after graduation. The target population consists of individuals having obtained a degree or a certificate of postsecondary studies from a public Canadian postsecondary educational institution (university, college, trade school) in the reference calendar year, or having satisfied the requirements for such a diploma or certificate. The survey 
excludes graduates from private postsecondary educational institutions and those having completed a continuing education program (mature students), unless they received a diploma or a certificate. Individuals who completed part-time trade programs or professional training courses lasting less than three months, or who did not live in Canada or the United States at the time of the survey, were also dropped from the sample. Although, the survey covered the classes of 1982 and 2000, for reasons of data availability, quality and comparability, only data for the 1986, 1990, and 1995 cohorts are used in this study. To facilitate the empirical estimations, we consider graduates having obtained a bachelor's degree or a first professional degree regrouped in seven fields of study: (1) "Education," (2) "Fine arts and humanities," (3) "Social sciences," (4) "Commerce and business," (5) "Agricultural and biological sciences," (6) "Health," and (7) "Sciences."

Some descriptive statistics are presented in Table 1. The data confirm the role of income in the choice of field of study. Nine out of ten graduates from 1990 and 1995 cohorts rank income prospects as important or very important in their choice of major. Almost all graduates from "Commerce and business," rank pecuniary considerations as very important while graduates from "Fine arts and humanities" assign less weight to income to explain their choice.. Similarly, a correspondence between field of study and employment was considered important or very important for nine out of ten 1990 graduates, an increase of eight points from 1986 (Information not available for the cohort of 1995). Once again, graduates from "Fine arts and humanities" stand out from the herd, since 15 out of 20 of them consider important the job-field of study relationship, compared to about 19 of 20 in the fields of "Education," "Commerce and business," "Health," and "Sciences." Thus, the labour market represented by income and the job-education skills match, is important in students' decisions of their field of study.

The NGS data permit to assess the relevance of young people's decisions. Over two thirds of graduates maintain that they would make the same (program) choice, if they had to do it over 
again. Either these students made good forecasts, or factors that are invariant, predominate in their decision functions. Graduates from "Education," "Health," and "Sciences" are relatively the most satisfied with their decision. Graduates from "Social sciences" and "Agriculture and biological sciences" would be most inclined to reconsider their original choice. Yet, those who would make a different choice may still pick a different program within the same broadly defined field of study.

Table 1 also indicates the proportion of graduates who relied on the student loans program to finance their studies. Eligibility for student loans depends on parents' participation in the cost of education. The student must, in fact, demonstrate financial need to qualify. Until 2004, students from families with annual income above \$ 60,000 were not eligible (Government of Canada, 2005). Thus, having recourse to a student loan can serve as a good proxy for the wealth of the graduate's family. A little over one half of the 1990 graduates borrowed money from the student loans program, while $42 \%$ of the class of 1995 described this means of financing as one of the two main sources of funding for their studies. A further indicator of the students' standard of living is their parents' level of education. We observe that the proportion of students with (at least) one parent having attended university is constantly rising, which is consistent with the upward trend in the proportion of the working age population pursuing university studies.

It is of some interest to note that barely half the graduates from the class of 1995 were holding a job closely related to their field of study two years after being awarded their diplomas. However, this proportion had risen significantly over time, since it was only 38\% for the 1990 cohort. This latter group seems to have been stymied by the recession of the early 1990s. The least likely to find a job in their field are graduates from "Fine arts and humanities", followed by "Agricultural and biological sciences" and "Social sciences." We note that these graduates assign the least importance to the job-education skill relationship. Conversely, the closest job-studies correspondence is found among "Health" and "Education" graduates. 
Two years after graduation, the average annual earnings of the class of 1995 were $\$ 33818$ (in constant 2000 Canadian dollars) for full-time workers (\$30 564 when part-time workers are included). This is $9.2 \%$ less than the corresponding mean for 1990 graduates. Nonetheless, three years later (i.e. five years after graduation), full-time workers from the 1995 cohort were earning $\$ 44326$ on average (\$42 198 when part-time workers are included), or $4.7 \%$ more than their 1990 counterparts. Consequently, even though they started from lower salaries, the 1995 graduates subsequently benefited from greater wage increases allowing them to recoup their gap with respect to the 1990 cohort. By field of study, the highest mean salaries are in "Health" and "Sciences," and the lowest in "Fine arts and humanities" and "Agricultural and biological sciences."

As shown in Table 2, earnings are on average higher when employment is directly related to the field of study. In the case of the class of 1995, the mean annual earnings (two years after graduation) were $20.2 \%$ higher when the job was directly related to the field of study. This premium was up considerably, since it was only $12.5 \%$ for 1990 graduates. If we only consider the 1995 cohort, the benefit of finding work related to one's studies is greatest for graduates in the "Social sciences" (+25.6\%) and "Education" (+22.0\%), and least in "Health" (+3.0\%) and "Sciences" $(+5.8 \%)$. Thus, our approach, consisting of assessing the value of expected income for each field of study while accounting for the job-studies relationship, proves to be well founded.

Finally, it is of some interest to note that the distribution of graduates across the seven fields of study, when the sexes are pooled, changed very little between 1990 and 1995, as borne out by Table 3. The observed variations fall within a one percentage point interval. However, we point that there was a 0.96 point increase in the share of "Social sciences" graduates and a 0.75 point decline in the share of "Health." By gender, we specifically note a 2.03 points increase in female graduates from "Social sciences" versus a 0.93 point decline in males graduating from the same major. On the other hand, the data in Table 3 indicate that women's likelihood of choosing studies 
in "Sciences" is approximately one fifth of men's. Conversely, women are more liable to opt for "Health" studies - a widely known fact. This educational segregation translates into occupational segregation, which in turn perpetuates the former. Thomas and Montmarquette (2005) argue that occupations in which there are more men than women are associated with academic disciplines that are also dominated by men such as technical and scientific fields. The same applies to occupations dominated by women, principally the field of health. The authors add that it is relatively easier to find work in a field in which one's gender has greater representation than where it does not. For example, a woman having studied engineering is liable to encounter hurdles on the job market, owing to prejudices amongst employers and within the workplace. It is thus prudent to study in a field in which one's sex is dominant or at least equally represented.

\section{Econometric Specifications}

Assume that there are $J$ fields of study offered at university. Assume also that the reduced-form expected utility index in the field of study $j$ can be expressed as follows (for convenience we omit the subscript $i$ related to individuals):

$$
U_{j}^{*}=\theta_{j} Z+\alpha y_{j}+\mu_{j}, j=1 \text { to } J
$$

$Z$ is a vector of observed individual-specific characteristics that influence students' choices, $y_{j}$ is $\log ^{\prime}$ lifetime earnings expected after graduation in field $\mathrm{j}$, and $\mu_{j}$ is a random component that captures unobserved variables. $\theta_{j}$ and $\alpha$ are parameters to be estimated. The utility of a field of study should increase as the expected earnings in this field increase implying $\alpha>0$.

Lifetime earnings expected in a field of study may depend upon the relationship between this field and the job held after graduation. As shown in Section II, earnings are on average higher in jobs that are related to studies, and a large proportion of students attach importance to this 
relationship (see Table 1). We propose to account for this fact in the prediction of the lifetime earnings in each field of study.

Conditional on the field of study $j$ being chosen, let $Y_{j}^{C}$ be the expected lifetime earnings if the job obtained after graduation is closely related to this field, $Y_{j}^{n}$ be the expected lifetime earnings if not, and $p_{j}$ be the perceived probability to find a job related to her field of study. Then, the expected log of lifetime earnings in the field $j$ is:

$$
y_{j}=p_{j} \ln \left(Y_{j}^{c}\right)+\left(1-p_{j}\right) \ln \left(Y_{j}^{n}\right)
$$

More correctly, this quantity is equal to $\ln \left[p_{j} Y_{j}^{c}+\left(1-p_{j}\right) Y_{j}^{n}\right]$, but we can show that the two specifications are almost equivalent.

A student chooses the field of study that maximizes her indirect utility. The latter is not observable; we rather observe the student's choice as given by the dummy variables: $D_{j}, j=1$ to $J$, with $D_{j}=1$ (the student chooses field $j$ ) if $U_{j}^{*}=\operatorname{Max}\left\{U_{1}^{*}, U_{2}^{*}, \ldots, U_{J}^{*}\right\}, D_{j}=0$ otherwise and $\sum_{j} D_{j}=1$ (the student chooses only one field).

Using discrete time like in Berger (1988), $Y_{j}^{k}, k=c, n$, is given as follows:

$$
Y_{j}^{k}=\sum_{t=0}^{\infty} \frac{R_{j t}^{k}}{(1+r)^{t}}
$$

where $R_{j t}^{k}$ represents earnings at time $t$, and $r$ is the individual discount rate. If we assume that earnings increase at a constant rate $g_{j}^{k}$, then $Y_{j}^{k}$ can be written as follows: 


$$
Y_{j}^{k}=R_{j 0}^{k} \sum_{t=0}^{\infty}\left(\frac{1+g_{j}^{k}}{1+r}\right)^{t}
$$

where $R_{j 0}^{k}$ represents initial earnings. For the quantity in (4) to be finite, the condition $g_{j}^{k}<r$ is required. In this case, this quantity simplifies to:

$$
Y_{j}^{k}=R_{j 0}^{k} \frac{1+r}{r-g_{j}^{k}}
$$

Then,

$$
\ln \left(Y_{j}^{k}\right)=\ln \left(R_{0 j}^{k}\right)-\ln \left(r-g_{j}^{k}\right)+\ln (1+r)
$$

Two important empirical facts are ignored in computing the lifetime earnings as given by Equation (5): the horizon is finite and the earnings profile is not linear toward the end of the life cycle. The consequences of ignoring these empirical facts at this point are, however, negligible for reasonable values of the discount rate (See Willis and Rosen, 1979, for a similar approach). A Taylor series approximation to the nonlinear term $\ln \left(r-g_{j}^{k}\right)$ in (6) around its population mean values $(\bar{g}, \bar{r})$ yields:

$$
\ln \left(Y_{j}^{k}\right) \approx \ln \left(R_{0 j}^{k}\right)+\frac{1}{\bar{r}-\bar{g}}\left(g_{j}^{k}-r\right)+\ln (1+r)=\delta_{0}+\delta_{1} \ln \left(R_{0 j}^{k}\right)+\delta_{2} g_{j}^{k}
$$

where $\delta_{1}=1, \delta_{2}=1 /(\bar{r}-\bar{g})>0$ and $\delta_{0}=\ln (1+r)-\delta_{2} r$. By combining Equations (2) and (7), the expected log of lifetime earnings in the field of study $j$ becomes:

$$
\begin{aligned}
y_{j} & =\delta_{0}+\delta_{1}\left[p_{j} \ln \left(R_{0 j}^{c}\right)+\left(1-p_{j}\right) \ln \left(R_{0 j}^{n}\right)\right]+\delta_{2}\left[p_{j} g_{j}^{c}+\left(1-p_{j}\right) g_{j}^{n}\right] \\
& =\delta_{0}+\delta_{1} E\left(\ln \left(R_{0 j}\right)\right)+\delta_{2} E\left(g_{j}\right)
\end{aligned}
$$


Finally, substituting (8) into (1), we obtain:

$$
U_{j}^{*}=\theta_{j} Z+\alpha_{1} E\left(\ln \left(R_{0 j}\right)\right)+\alpha_{2} E\left(g_{j}\right)+\mu_{j}, j=1 \text { to } J
$$

In practice, a student can only select a single field of study. Consequently, $p_{j}, R_{j 0}^{k}$ and $g_{j}^{k}$ are censored for the fields that the student did not choose. Even in the same field of study, for each graduate we only observe earnings for one type of employment (either related or not to studies). In the case of a single earnings equation by field of study (i.e., when ignoring the connection between employment and studies), one solution to the selection problem would be to estimate earnings adjusted for selectivity bias and then to use coefficient estimates to predict individual earnings for each field of study (see Lee, 1978; Willis and Rosen, 1979; Berger, 1988; and Boudarbat, 2004). ${ }^{1}$ However, the reliability of this econometric technique depends crucially on the availability of instruments that can impact the choice of field of study without having any impact on individual earnings (exclusion conditions). Though it is possible to identify and provide a rationale for some instruments, it is far from clear that they will be found in survey data. In their discussion of the identification problem, Willis and Rosen (1979) assert that variables relative to family background are good instruments for investment in education. In our case, we find the NGS to be particularly poor in this type of data. Aside from parents' education and recourse to the student loans program, the survey provides no information on the socio-economic background of the graduates.

Furthermore, our model introduces a second level of selectivity owing to the fact that, for each field of study, graduates may, or may not, find corresponding employment. This adds further complications to the correction for selectivity bias.

\footnotetext{
1 The adjustment procedures are those proposed by Heckman (1979) or Lee (1983). Montmarquette, Cannings and Mahseredjian (2002) questioned the pertinence of such approach in the non linear context introduced by the concept of expected earnings.
} 
The approach we propose here differs from the one based on adjusting for selectivity bias. We assume that, at the moment of the choice of field of study, students evaluate their expected lifetime income on the basis of data on graduates who are already on the market. In the context of NGS data, this is tantamount to assuming that 1990 graduates used data on the 1986 cohort as a reference, while the class of 1995 used data for that of 1990. Econometrically, the coefficients used to predict the expected lifetime incomes of students in a given cohort are estimated from data on the preceding cohort. The benefit of this approach is that the coefficients in question are independent of (exogenous to) the sample for which we are analysing the field of study selection process. Furthermore, combining cross-field and cross-time variation provides a credible source of variation in the returns to field of study. Thus, changes in the returns to studying in a particular field can be used to see how the field choices of new cohorts of students respond to these changing conditions.

Subsequently, three sets of equations are added to model (9):

$$
\begin{aligned}
& I_{j}^{*}=\lambda_{j} X_{1}+\xi_{j} \\
& \ln \left(R_{j 0}^{k}\right)=\beta_{j}^{k} X_{2}+\varepsilon_{j}^{k} \\
& g_{j}^{k}=\phi_{j}^{k} X_{3}+\tau_{j}^{k} j=1 \text { to } J ; k=c, n
\end{aligned}
$$

$I_{j}^{*}$ is a latent variable that allows the switching between the two situations $k=c\left(I_{j}^{*} \geq 0\right.$, the job is related to the field of study) and $k=n\left(I_{j}^{*}<0\right.$, the job is not related to the field of study). The quantities $\ln \left(R_{j 0}^{k}\right)$ and $g_{j}^{k}$ are respectively log initial (annual) earnings and the earnings' rate of growth of situations $k$ and $n . X_{1}, X_{2}$ and $X_{3}$ are vectors of observed characteristics. $X_{1}$ includes age (two years after graduation), education level and work experience before starting the bachelor's 
program, absence or interruption of studies during the program, studies intensity (full or part time), marital status and province of residence. Variables in $X_{2}$ are age (two years after graduation), education level and work experience before starting the bachelor's program, marital status, $\log$ number of weekly worked hours, and province of residence. Finally, $X_{3}$ contains the same set of variables as $X_{2}$. The probability of finding a job related to the field of study if the field $j$ is chosen is $p_{j}=\operatorname{Prob}(k=c)=\operatorname{Prob}\left(I_{j}^{*} \geq 0\right)$.

Estimation of the model (9) occurs in two stages. In the first stage the coefficients of the equations (10) to (12) are estimated using data from the 1986 (1990) cohort. The first equation is estimated using a probit model, and the other two equations with OLS. To account for differences between men and women, each equation includes a dummy representing women, which is crossed with all other explanatory variables in $X_{1}, X_{2}$ and $X_{3}$, including the constant terms, .

The estimated coefficients are used to generate predictions of $\ln \left(R_{j 0}^{k}\right), g_{j}^{k}$ and $p_{j}$, which in turn yield predictions of $E\left(\ln \left(R_{0 j}\right)\right)$ and $E\left(g_{j}\right),($ Equation 8), for graduates in the 1990 (1995) cohort. The predicted values $\hat{E}\left(\ln \left(R_{0 j}\right)\right)$ and $\hat{E}\left(g_{j}\right)$ are then substituted for $E\left(\ln \left(R_{0 j}\right)\right)$ and $E\left(g_{j}\right)$ in Equation (9).

In the second stage, we estimate (9) using a multinomial logit model. We assume that the stochastic terms $\mu_{j}$ are independent and follow a Gumbell (or Type I extreme-value) distribution. In this case, the probability of choosing discipline $j$ is:

$$
\operatorname{Prob}\left(D_{j}=1 \mid Z, \hat{E}\left(\ln \left(R_{0 k}\right)\right)_{k=1, \ldots, J}, \hat{E}\left(g_{j}\right)_{k=1, \ldots, J}\right)=\frac{\exp \left(\theta_{j} Z+\alpha_{1} \hat{E}\left(\ln \left(R_{0 j}\right)\right)+\alpha_{2} \hat{E}\left(g_{j}\right)\right)}{\sum_{k=1}^{J} \exp \left(\theta_{k} Z+\alpha_{1} \hat{E}\left(\ln \left(R_{0 j}\right)\right)+\alpha_{2} \hat{E}\left(g_{k}\right)\right)}
$$


This corresponds to the multinomial logit (mixed) model of McFadden (1973). ${ }^{2}$ In order to identify field-specific parameters, the parameters of a (reference) field should be set to 0 . Also, we produce robust standard errors of parameter estimates in case of heteroscedasticity from the twostage estimation.

In the empirical estimation we test whether the weight put on earnings varies when parents have university education by crossing the expected lifetime earnings in each field of study with two dummy variables indicating if the father and the mother have university education. We also include parents' education level in vector Z. Our data set does not include information on family income, but Drolet (2005) finds that parents' education stand out as being more important than parents' earnings in the decision to attend university. We incorporate a variety of other variables into vector $Z$. These are: age at the beginning of the program of study, marital status (single or not), recourse to student loans to finance studies, duration of studies, the time allocated to school (fullor part-time), the importance imputed to the factors "skills acquisition," "knowledge acquisition," and "income" in the choice of field of study and, finally, the province of residence 12 months prior to starting the university program. We also include a dummy variable which takes value 0 for the cohort 1990 and value 1 for the cohort 1995. Recourse to student loans likely reflects the family's wealth. Of the retained variables, only marital status is liable to change over time, especially between the time of the choice of program of studies and the time of the observation. We retain this variable's value five years after graduation as a proxy for women's attachment to the labour force.

As mentioned earlier, we limited our sample to graduates having obtained a bachelor's degree or a first professional degree. Adding further levels of education would require modelling the vertical choice of education level in addition to the horizontal choice of field of study within

\footnotetext{
2 The model is also called mixed because it includes two types of coefficients, one of which is invariant to the choice of field of study. The model is some times called conditional multinomial logit.
} 
each level. While this exercise is theoretically possible, empirical estimation of the resulting model would be of particular technical difficulty.

In the model we estimate, the job-field of study relationship and the initial annual earnings pertain to the job held two years after graduation (first NGS wave). Information on the job-field of study relationship is not provided during the second wave (i.e., five years after graduation). To counter this limitation in the data, we are compelled to assume that the initially observed job-field of study relationship (two years after graduation) is maintained thereafter. Consequently, the growth rate of annual earnings is approximated by the (constant) mean annual growth rate between the two waves.

\section{Empirical Results}

Model (9) is estimated using data from a sample of 12,046 graduates having obtained a bachelor's degree, 6,787 are from the 1990 cohort and 5,259 from the 1995 cohort. Women represent 55\% of both sub samples. Furthermore, data for a sample of 6,662 graduates from the class of 1986 was used to estimate the coefficients of equations (10), (11) and (12), which in turn served to generate predictions of the probability of finding a job corresponding to the field of study and of the initial income and its annual growth rate for the 1990 cohort. The same method was used to obtain predictions for the class of 1995 from 1990 data. Our interest with equations (10) to (12) estimates is to overcome the selection problem in measuring the impact of expected lifetime income variable on the choice of field of study. Results, available upon request, show that the predicted probabilities of finding a job related to the field of study are much higher in Education and Health, in particular for females. In accord with the descriptive statistics, expected log initial earnings are higher in job related studies, and are the highest in the field "Health" followed by "Sciences" and "Education", and the lowest in the fields "Agricultural and biological sciences" and "Fine arts and humanities." 
An interesting result is that the expected earnings' rate of growth is higher in the low initial earnings fields for females and males, which causes the earning gaps between fields to narrow over time. However, with a rate that is twice higher than in "Health," graduates from "Sciences" make up fast their gap with respect to graduates from "Health" and are expected to stand out from the herd in the future.

In Table 4, we present the estimated coefficients on the choice of field of study (equation 9) of the expected log initial earnings and the expected earnings' rate of growth, which are field invariant. As mentioned earlier, we allow those coefficients to vary according to gender and the level of education of parents. First, the estimated coefficients on the expected log initial earnings and on its expected growth rate are positive and significant for both men and women. The results, which are unequivocal for students without both parents having a university degree, suggest that an increase in the return to a field of study increases the probability that these students choose this field. Second, the highly significant positive coefficient on the expected earnings' rate of growth bolsters the argument that students are influenced by lifetime earnings and not only by the initial earnings as strongly defended by Berger (1988). Third, men put more weight on initial earnings compared to women, whilst the later put more weight on the expected earnings' rate of growth. An important result that emerges from Table 4 is that the role of earnings when choosing a field differs strongly when the parents have a university education. Wald tests indicate that when both parents have university education, the weight put on initial earnings is not significantly different from zero for both genders. Thus, students with both parents having university education are likely to come from affluent families, which make them less sensitive to initial pecuniary returns on education. The situation is more complex with a single parent has a university degree. Wald test indicate that the log initial earnings variable is statistically non significant for a female student whose mother has university education, and for a male student whose father has university education. 
Females' response to changes in earnings growth also differ depending upon their parents' education while it does not affect males. A student woman with her mother holding a university degree appears unaffected by the earnings rate of growth in choosing her field of study, thus leaving more room to non pecuniary factors to explain her choice, .These behavioural differences strengthen the case for accounting for different socio-economic realities confronting men and women in their choice of field of study.

To evaluate earnings variations impact on students' choices, Table 5 shows the marginal effects of earnings changes on the likelihood of choosing each field of study for students with no parent declaring a university degree. Accounting for the interaction with parents' university education is a rather cumbersome exercise with the end-results, basically weakening the marginal effect of earnings changes for those with university educated parents. The directions of the estimated effects are consistent with the previous statement that increased log lifetime earnings (either through initial earnings or earnings' rate of growth) in a specific field of study (while holding all else constant) increases the probability of choosing this field and reduces the probability of choosing any of the competing fields. In addition, all marginal effects are highly significant. Yet, results give rise to a fundamental conclusion. A substantial increase in lifetime earnings would be necessary to draw students into fields of study they are not inclined to choose initially. For instance, if expected initial earnings in "Education" increase by $10 \%$, the probability of choosing this field will only increase by 0.015 for women and 0.011 for men. ${ }^{3}$ Our model's results still support the view that an unfettered market is capable of aligning the supply with the demand for skilled labour. In simple terms, an increase in demand in a profession should be associated with expected rising salaries, since supply cannot adjust immediately. These expected higher salaries

\footnotetext{
${ }^{3}$ A unit increase in $\log$ X corresponds approximately to $100 \%$ increase in X. A $10 \%$ increase effect is calculated by dividing the marginal effect by 10 .
} 
are, in turn, liable to boost the proportion of students opting for the field of study corresponding to the profession in demand. Similarly, if the supply of labour overshoots demand, salaries will be driven down, which will reduce the supply. However, some public policies, such as a funding system for public education that is disconnected from labour market signals, can have the effect of impeding that interplay of market forces and prolonging any disequilibrium, whether perceived or real, between the demand for, and supply of, skilled labour. Also, any labour market rigidity that keeps the market from sending signals that reflect the true state of the market will impair this adjustment.

The multinomial logit coefficients are cumbersome to interpret when they are field-specific so we choose to comment the marginal effects, which are presented in Table $6 .{ }^{4}$ Results are presented in a way that facilitates the comparison between men and women. They should be interpreted as the effect of a unit change in a covariate on the probability of choosing a given field of study, ceteris paribus. For a dichotomous variable, this marginal effect measures the discrete change in the probability of choosing a specific field of study when this variable switches from 0 to 1, holding all else constant. All the marginal effects were estimated at the means of the covariates.

First, let examine the direct effect of parents' education on children' choices (by ignoring its effect through the weight put on expected earnings.) A mother having a university education is liable to be associated with her daughter(s) taking up "Health" and shunning "Education." This same mother, however, is likely to impart a tendency amongst her son(s) to study "Agricultural and biological sciences." On the other hand, a father having acquired a university education is liable to increase the likelihood that his daughter(s) will pursue the fields "Fine arts and humanities" or "Agricultural and biological sciences" to the detriment of the fields "Social Sciences." This same father is likely to increase the probability that his son(s) will choose "Health"

\footnotetext{
4 The multinomial logit model coefficient estimates are available upon request by contacting the authors.
} 
and shun "Education." Hence, a student (male or female) is likely to choose "Health" and to avoid "Education" when the parent of the same sex has university education. In sum, it is important to distinguish between the mother's and the father's level of education. The probability of choosing "Agricultural and biological sciences" augments among men whose mothers have secondary or college diplomas. When the father has secondary or college diploma, male students are less likely to choose "Education." Overall, there is limited impact of parents on their children's choices when parents have less than university education.

From another perspective, students (females and males) who obtain a student loan, another indicator of family affluence, are less prone to study "Commerce and business". They are, however, slightly more inclined toward "Agricultural and biological sciences." Moreover, the probability of choosing studies in "Social sciences" increases for women who obtain a student loan. 5 In general, obtaining a student loan has less impact on men's decisions compared to women.

The impact of the time allocated to school on the choice of discipline may be of particular interest. The majors most likely to attract students (females or males) unable to commit themselves to full-time studies are "Social sciences" and "Commerce and business." At the other end of the spectrum, those inclined to study full-time are liable to opt for studies in "Sciences" or "Health" for both gender in addition to "Education" in the case of women. Students who pursue their studies part-time probably do so in order to be able to continue working simultaneously and draw an income, but the forgone earnings associated with studies in "Sciences" and "Health" are compensated by higher pay after graduation.

\footnotetext{
5 Student loans program (both at the federal and the provincial levels) is not intended to affect the choice of fields of study. The main objective of this program is to alleviate some financial constraints to investment in postsecondary education. Hence, the estimated effects of obtaining a student loan on the choice of fields of study are, indirectly, those of the family economic background.
} 
An important fact that emerges from Table 6 is that the goals that students seek to attain through their education, especially acquiring skills, stand out as being among the most influential factors in their choices. Thus, "Education," "Commerce and business," "Health," and "Sciences" are the fields of predilection for students seeking to acquire skills. Conversely, this group is much less likely to opt for studies in "Fine arts and humanities" or "Social sciences." In this way, students appear to identify fields of study with more or less specific vocations. The fields "Education," "Commerce and business," "Health," and "Sciences" lead to very precise occupations (e.g., teacher, commercial agent, physician, engineer) while, in the opinion of students, "Fine arts and humanities" and "Social sciences" have broader vocations.

When the aim is acquiring knowledge, the field "Health" is also a discipline of choice for both female and male students. The latter are also inclined to choose "Education." The genders differ on the fields they associate with less possibility of acquiring knowledge. Indeed, women pursuing such objective will tend to avoid the field of "Commerce and business," whereas men in the same situation are more inclined to shun "Social sciences."

It is also interesting to note that female and male students who assign a great deal of weight to income are more likely to choose studies in "Commerce and business" and much less liable to opt for "Fine arts and humanities." This latter field of study is the least lucrative (Table 2), while "Commerce and business" appears to continue to have a reputation associating it with high expected earnings. Male students who aim at getting high income are also more inclined to select "Sciences."

Finally, we observe that married women (or those who marry within the five years covered) tend to opt for studies in "Education" or "Health." These two fields appear to be particularly suited to reconciling family and work. Conversely, women who are single (or remain single within the 
five years covered) tend to select studies in "Fine arts and humanities," "Social sciences" or "Agricultural and biological sciences."

\section{Conclusion}

In this study we examine the determinants of the choice of field of study made by students enrolling in university programs at the level of the bachelor degree. More specifically, we seek to measure the impact of labour-market variables, represented here by expected lifetime income after graduation. Our model distinguishes if the job held after graduation is linked to the field of study. Empirical data indicates a substantial wage gap between employment that is connected to studies and employment that is not. The model is estimated using data from the Canadian National Graduate Survey for the classes of 1986, 1990, and 1995.

Our estimates demonstrate that expected lifetime income has a significant influence on students when they are choosing their field of study for students whose parents have no university degree. Furthermore, as in the case of other studies, we observe an impact of expected lifetime income that is differentiated by sex. Men put more weight on initial earnings compared to women, whilst the later put more weight on the expected earnings' rate of growth. We also conclude that substantial variations in expected income are necessary to attract students into disciplines they would normally shun, ceteris paribus.

An important fact that emerges from our results is that the weight that a female student puts on earnings when choosing a field of study is not statistically significant when her mother has a university education. This weight is also significantly reduced, but is still positive and statistically significant, for a male student having a father with university education. The impact of parents' education, separately from earnings, is also a function of the parent's and the child's sex. We observe a mother's bias in favour of, or a father's bias against a given field of study. The 
relationship between parents' education and children' choices is worthy of further research given the ongoing rise in university enrolment in Canada.

Other factors play a role in students' choices. Notably, marital status, and the vocation identified with each field of study (the acquisition of skills or knowledge). Women who are not single are more liable to opt for "education" or "Health." Furthermore, students who put more weight on acquiring skills (knowledge) are more prone to choose fields of study they identify with this vocation.

If market conditions matter to choose a field of study, gender and the level of education of parents also matter significantly. From a policy perspective, a substantial increase in lifetime earnings, while all other factors remain constant, would be necessary to draw students into fields of study they are not inclined to choose initially. 


\section{References}

Arcidiacono, P. (2004), "Ability Sorting and the Returns to College Major," Journal of Econometrics, $121,343-375$.

Berger, M.C. (1988), "Predicted Future Earnings and Choice of College Major," Industrial and Labour Relations Review, 41, 418-429.

Blakemore, A. E. and S. A. Low (1984), "Sex Differences in Occupational Selection: The Case of College Majors," The Review of Economics and Statistics, 66(1) , 157-163.

Boothby, D. (1999), "Earnings Differences by Detailed Field of Study of University Graduates," Applied Research Branch, Strategic Policy, Human Resources Development Canada, R-00-1$5 \mathrm{E}$.

Borghans L. and L. Groot (1999), "Educational pre-sorting and educational segregation," Labour Economics 6, 375-395.

Boudarbat, B. (2004). "Earnings and the Choice of the College Field of Study in Canada," forthcoming in Economics of Education Review.

Card, D. (1999), "The Causal Effect of Education on Earnings," In Orley Ashenfelter and David Card, editors, Handbook of Labor Economics, 3, Amsterdam: Elsevier Science.

Drolet, Marie (2005), "Participation aux études postsecondaires au Canada : le rôle du revenu et du niveau de scolarité des parents a t il évolué au cours des années 1990?" Direction des études analytiques (Statistique Canada) - document de recherche no 243.

Finnie, R. (1999), "Earnings of University Graduates in Canada by Discipline. Fields of Plenty, Fields of Lean. A Cross-Cohort Longitudinal Analysis of Early Labour Market Outcomes," Applied Research Branch Strategic Policy. Human Resources Development Canada. R-99-13E.a.

Government of Canada (2005), "Canada Student Loans Program for Full-time Students - Investing in Your Future 2005-2006," HRIC-076-03-05E.

Heckman, J. (1979), “Sample Selection Bias as a Specification Error,” Econometrica 47,153-161.

Lee, L.F. (1978), "Unionism and Wage Rates: A Simultaneous Equations Model with Qualitative and Limited Dependent Variables," International Economic Review, 19 (2), 415-433.

Lee, L.F. (1983), “Generalized Econometric Models with Selectivity," Econometrica, 51 (2), 507-512.

McFadden, D. (1973), "Conditional Logit Analysis of Qualitative Choice Behavior," In Frontiers in Econometrics, Ed. By P. Zarembka. New York : Academic Press.

Montmarquette, C., K. Cannings, and S. Mahseredjian (2002), “How do Young People Choose College Majors?" Economics of Education Review, 21(6), 543-556.

Paglin, M. and A.M. Rufolo (1990), "Heterogeneous Human Capital, Occupational Choice, and Male-Female Earnings Differences," Journal of Labor Economics, 8 (1), 123-144.

Polachek, S. W. (1978), "Sex Differences in College Major," Industrial and Labor Relations Review, 31 (4), 498-508. 
Thomas, L. and C. Montmarquette (2005), "La présélection éducationnelle et la ségrégation professionnelle. Le cas du Québec et de 1'Ontario en 1997," rapport de projet 2005RP-02, CIRANO.

Willis, R.J. and Rosen, S. (1979), "Education and Self-Selection," The Journal of Political Economy, 87 (5), Part 2: Education and Income Distribution, S7-S36. 
Table 1

Some Descriptive Statistics

\begin{tabular}{|c|c|c|c|c|c|c|c|c|c|}
\hline & & Education & $\begin{array}{l}\text { Fine arts, } \\
\text { humanities }\end{array}$ & $\begin{array}{c}\text { Social } \\
\text { sciences }\end{array}$ & $\begin{array}{l}\text { Commerce } \\
\text { business }\end{array}$ & $\begin{array}{l}\text { Agricultural } \\
\text { biological } \\
\text { sciences }\end{array}$ & Health & Sciences & Total \\
\hline \multirow{2}{*}{$\begin{array}{l}\text { Improving their chances for a high income was } \\
\text { important, or very important, to their choice of } \\
\text { field of study }\end{array}$} & 1990 & 0.92 & 0.78 & 0.92 & 0.96 & 0.87 & 0.86 & 0.93 & 0.90 \\
\hline & 1995 & 0.93 & 0.81 & 0.89 & 0.96 & 0.92 & 0.95 & 0.92 & 0.90 \\
\hline $\begin{array}{l}\text { Deem the job- field of study relationship } \\
\text { important or very important }\left(^{*}\right)\end{array}$ & 1990 & 0.95 & 0.76 & 0.85 & 0.94 & 0.87 & 0.96 & 0.94 & 0.88 \\
\hline \multirow{2}{*}{$\begin{array}{l}\text { Would pick the same field of study if they had to } \\
\text { make the choice again }\end{array}$} & 1990 & 0.80 & 0.68 & 0.64 & 0.70 & 0.62 & 0.82 & 0.77 & 0.71 \\
\hline & 1995 & 0.77 & 0.67 & 0.59 & 0.70 & 0.59 & 0.76 & 0.74 & 0.68 \\
\hline \multirow{2}{*}{ Obtained student loans $\left({ }^{* *}\right)$} & 1990 & 0.55 & 0.49 & 0.51 & 0.45 & 0.58 & 0.58 & 0.52 & 0.52 \\
\hline & 1995 & 0.47 & 0.36 & 0.42 & 0.36 & 0.42 & 0.46 & 0.44 & 0.42 \\
\hline \multirow{2}{*}{ Mother and/or father is a university graduate } & 1990 & 0.38 & 0.46 & 0.37 & 0.36 & 0.47 & 0.44 & 0.43 & 0.40 \\
\hline & 1995 & 0.42 & 0.47 & 0.40 & 0.40 & 0.50 & 0.45 & 0.42 & 0.43 \\
\hline \multirow{2}{*}{$\begin{array}{l}\text { Their employment is closely related to their field } \\
\text { of study (two years after graduation) }\left(^{* * *}\right)\end{array}$} & 1990 & 0.48 & 0.28 & 0.29 & 0.38 & 0.33 & 0.74 & 0.37 & 0.38 \\
\hline & 1995 & 0.70 & 0.29 & 0.33 & 0.57 & 0.32 & 0.77 & 0.59 & 0.49 \\
\hline
\end{tabular}

$\left.{ }^{*}\right)$ This question was not asked of the class of 1995 .

${ }^{* *}$ The 1990 data captures any borrowing within the student loan program, while in 1995 it was only included if it was one of the two principal sources of funding for the studies. This difference explains the substantial drop in the percentages between 1990 and 1995.

$\left.{ }^{* * *}\right)$ This information is directly provided in the data file (and not derived by the authors). 
Table 2

Mean Annual Earnings Two Years after Graduation, by Fields of Study and Relationship Job-Major, Full-Time Workers (in 2000\$)

\begin{tabular}{|c|c|c|c|c|c|c|}
\hline & \multicolumn{2}{|c|}{1986} & \multicolumn{2}{|c|}{1990} & \multicolumn{2}{|c|}{1995} \\
\hline & $\begin{array}{l}\text { Partly or } \\
\text { not related }\end{array}$ & $\begin{array}{l}\text { Directly } \\
\text { related }\end{array}$ & $\begin{array}{l}\text { Partly or } \\
\text { not related }\end{array}$ & $\begin{array}{l}\text { Directly } \\
\text { related }\end{array}$ & $\begin{array}{l}\text { Partly or } \\
\text { not related }\end{array}$ & $\begin{array}{l}\text { Directly } \\
\text { related }\end{array}$ \\
\hline \multirow{2}{*}{ Education } & 32532 & 35743 & 37327 & 40019 & 28516 & 34800 \\
\hline & $(16098)$ & $(19968)$ & $(13455)$ & $(38360)$ & $(12$ 321) & $(8221)$ \\
\hline \multirow{2}{*}{ Fine arts, humanities } & 29324 & 31101 & 28637 & 33152 & 28234 & 31985 \\
\hline & $(17414)$ & $(13081)$ & (13 913) & $(13304)$ & (11 934) & $(13017)$ \\
\hline \multirow{2}{*}{ Social sciences } & 30412 & 39820 & 37147 & 42914 & 28450 & 35726 \\
\hline & (13 154) & $(56063)$ & $(62620)$ & $(46781)$ & (11 580) & $(12771)$ \\
\hline \multirow{2}{*}{ Commerce, Business } & 35539 & 37313 & 35166 & 36692 & 33198 & 36184 \\
\hline & (31 616) & (11 936) & (28 205) & $(22$ 107) & (10 391) & $(14$ 252) \\
\hline \multirow{2}{*}{$\begin{array}{l}\text { Agricultural and } \\
\text { biological sciences }\end{array}$} & 26503 & 32091 & 27208 & 34795 & 27605 & 30720 \\
\hline & $(14730)$ & $(10888)$ & $(11310)$ & $(16795)$ & $(10369)$ & $(11369)$ \\
\hline \multirow{2}{*}{ Health } & 40334 & 40831 & 42117 & 43646 & 42196 & 43446 \\
\hline & (41 331) & (25 954) & (12 098) & (14 210) & $(13805)$ & $(10320)$ \\
\hline \multirow{2}{*}{ Sciences } & 36672 & 38931 & 39437 & 41216 & 38618 & 40843 \\
\hline & (14 953) & $(8810)$ & (11 323) & $(17331)$ & (13 994) & (9610) \\
\hline \multirow{2}{*}{ Total } & 31948 & 37204 & 35518 & 39956 & 30645 & 36842 \\
\hline & (19 580) & $(24712)$ & (37 567) & (30 617) & (12 554) & (11 794) \\
\hline
\end{tabular}

Note: Figures in parentheses are standard-deviations. Data are weighted.

Table 3

Distribution of Graduates over Fields of Study (\%)

\begin{tabular}{lccccccccc}
\hline & \multicolumn{3}{c}{ Males } & \multicolumn{3}{c}{ Females } & \multicolumn{3}{c}{ Both Genders } \\
\hline & 1986 & 1990 & 1995 & 1986 & 1990 & 1995 & 1986 & 1990 & 1995 \\
\hline Education & 10.16 & 12.13 & 12.79 & 20.43 & 21.27 & 20.52 & 15.82 & 17.35 & 17.48 \\
\hline Fine arts, humanities & 13.35 & 12.53 & 11.97 & 20.47 & 17.98 & 18.79 & 17.28 & 15.64 & 16.11 \\
\hline Social sciences & 20.89 & 25.09 & 24.16 & 27.48 & 27.88 & 29.91 & 24.53 & 26.69 & 27.65 \\
\hline Commerce, business & 16.36 & 15.81 & 16.18 & 10.64 & 11.29 & 10.38 & 13.20 & 13.23 & 12.66 \\
\hline $\begin{array}{l}\text { Agricultural and } \\
\text { biological sciences }\end{array}$ & 7.02 & 5.98 & 6.75 & 6.05 & 6.99 & 6.63 & 6.49 & 6.56 & 6.68 \\
\hline Health & 2.37 & 4.69 & 3.81 & 8.19 & 9.46 & 8.51 & 5.58 & 7.41 & 6.66 \\
\hline Sciences & 29.86 & 23.76 & 24.33 & 6.74 & 5.13 & 5.27 & 17.11 & 13.13 & 12.77 \\
\hline Total & 100.00 & 100.00 & 100.00 & 100.00 & 100.00 & 100.00 & 100.00 & 100.00 & 100.00 \\
\hline
\end{tabular}


Table 4

Estimated Coefficients on the Choice of Field of Study of Expected Log Lifetime Earnings (equation 9)

\begin{tabular}{|c|c|c|c|c|}
\hline & \multicolumn{2}{|c|}{ Females } & \multicolumn{2}{|c|}{ Males } \\
\hline & Coef. & Std. Err. & Coef. & Std. Err. \\
\hline log initial (annual) earnings (1) & $0.9021^{* *}$ & 0.2228 & $1.1252^{* *}$ & 0.2102 \\
\hline $\begin{array}{l}\mathrm{x} \text { The father has a university } \\
\text { education (2) }\end{array}$ & 0.0808 & 0.3863 & $-0.7072^{*}$ & 0.3590 \\
\hline $\begin{array}{l}x \text { The mother has a university } \\
\text { education (3) }\end{array}$ & $-1.1744^{* *}$ & 0.3973 & 0.0553 & 0.3990 \\
\hline Earnings rate of growth (4) & $0.0362^{* *}$ & 0.0083 & $0.0248^{* *}$ & 0.0094 \\
\hline $\begin{array}{l}x \text { The father has a university } \\
\text { education (5) }\end{array}$ & -0.0096 & 0.0156 & 0.0027 & 0.0148 \\
\hline $\begin{array}{l}x \text { The mother has a university } \\
\text { education (6) }\end{array}$ & $-0.0333^{*}$ & 0.0170 & 0.0130 & 0.0168 \\
\hline
\end{tabular}

Standard errors are robust; $\left({ }^{*}\right)$ and $\left(^{* *}\right)$ : significant at the level of 5 and 1 percent (Two-tailed test).

Wald tests:

Females:

$\mathrm{H}_{0}:(1)+(2)+(3)=0$

$\mathrm{H}_{0}:(1)+(2)=0$

$\mathrm{H}_{0}:(1)+(3)=0$

$\mathrm{H}_{0}:(4)+(5)+(6)=0$

$\mathrm{H}_{0}:(4)+(5)=0$

$\mathrm{H}_{0}:(4)+(6)=0$
P_value $=0.6034$

$P_{\text {_tvalue }}=0.0092$

P_value $=0.4892$

$P_{\text {_value }}=0.6525$

P_value $=0.0723$

$P_{\text {_value }}=0.8626$
Males:

$\mathrm{H}_{0}:(1)+(2)+(3)=0$

$\mathrm{H}_{0}:(1)+(2)=0$

$\mathrm{H}_{0}:(1)+(3)=0$

ue $=0.1717$

$P_{\text {_value }}=0.2309$

$P_{\text {_value }}=0.0033$

$\mathrm{H}_{0}:(4)+(5)+(6)=0$

$P_{\text {_value }}=0.0048$

$\mathrm{H}_{0}:(4)+(5)=0$

$\mathrm{H}_{0}:(4)+(6)=0$
P_value $=0.0467$

$P_{\text {_value }}=0.0293$ 
Table 5

Marginal Effects of Earnings on the Probability of Choosing Each Field of Study

\begin{tabular}{|c|c|c|c|c|c|c|c|c|c|c|c|c|c|c|}
\hline & \multicolumn{2}{|c|}{ Education } & \multicolumn{2}{|c|}{$\begin{array}{c}\text { Fine arts, } \\
\text { humanities }\end{array}$} & \multicolumn{2}{|c|}{ Social sciences } & \multicolumn{2}{|c|}{$\begin{array}{c}\text { Commerce, } \\
\text { business }\end{array}$} & \multicolumn{2}{|c|}{$\begin{array}{c}\text { Agricultural, } \\
\text { biological sciences }\end{array}$} & \multicolumn{2}{|c|}{ Health } & \multicolumn{2}{|c|}{ Sciences } \\
\hline & Females & Males & Females & Males & Females & Males & Females & Males & Females & Males & Females & Males & Females & Males \\
\hline \multicolumn{15}{|c|}{ log initial earnings in : } \\
\hline Education & $\begin{array}{c}0.1513^{* * *} \\
(0.0380)\end{array}$ & $\begin{array}{c}0.1077^{* * *} \\
(0.0218) \\
\end{array}$ & $\begin{array}{c}-0.0333^{* * *} \\
(0.0085) \\
\end{array}$ & $\begin{array}{c}-0.0144^{* * *} \\
(0.0031) \\
\end{array}$ & $\begin{array}{c}-0.0598^{* * *} \\
(0.0151)\end{array}$ & $\begin{array}{c}-0.0312^{* * *} \\
(0.0064) \\
\end{array}$ & $\begin{array}{c}-0.0202^{* * *} \\
(0.0053)\end{array}$ & $\begin{array}{c}-0.0217^{* * *} \\
(0.0046) \\
\end{array}$ & $\begin{array}{c}-0.0108^{* * *} \\
(0.0028) \\
\end{array}$ & $\begin{array}{c}-0.0060^{* * *} \\
(0.0012) \\
\end{array}$ & $\begin{array}{c}-0.0181^{* * *} \\
(0.0046)\end{array}$ & $\begin{array}{c}-0.0031^{* * *} \\
(0.0007) \\
\end{array}$ & $\begin{array}{c}-0.0092^{* * *} \\
(0.00250 \\
\end{array}$ & $\begin{array}{c}-0.0312^{* * *} \\
(0.0065) \\
\end{array}$ \\
\hline $\begin{array}{l}\text { Fine arts, } \\
\text { humanities }\end{array}$ & $\begin{array}{c}-0.0333^{* * *} \\
(0.0085) \\
\end{array}$ & $\begin{array}{c}-0.0144^{* * *} \\
(0.0031) \\
\end{array}$ & $\begin{array}{c}0.1291^{* * *} \\
(0.0322) \\
\end{array}$ & $\begin{array}{c}0.1183^{* * * *} \\
(0.0233) \\
\end{array}$ & $\begin{array}{c}-0.0485^{* * *} \\
(0.0121) \\
\end{array}$ & $\begin{array}{c}-0.0348^{* * *} \\
(0.0070) \\
\end{array}$ & $\begin{array}{c}-0.0164^{* * *} \\
(0.0042) \\
\end{array}$ & $\begin{array}{c}-0.0242^{* * *} \\
(0.0050) \\
\end{array}$ & $\begin{array}{c}-0.0087^{* * *} \\
(0.0022) \\
\end{array}$ & $\begin{array}{c}-0.0067^{* * *} \\
(0.00130 \\
\end{array}$ & $\begin{array}{c}-0.0147^{* * *} \\
(0.0037) \\
\end{array}$ & $\begin{array}{c}-0.0035^{* * *} \\
(0.0008) \\
\end{array}$ & $\begin{array}{c}-0.0075^{* * *} \\
(0.0020) \\
\end{array}$ & $\begin{array}{c}-0.0348^{* * * *} \\
(0.0070) \\
\end{array}$ \\
\hline $\begin{array}{l}\text { Social } \\
\text { sciences }\end{array}$ & $\begin{array}{c}-0.0598^{* * *} \\
(0.0151) \\
\end{array}$ & $\begin{array}{c}-0.0312^{* * *} \\
(0.0064)\end{array}$ & $\begin{array}{c}-0.0485^{* * *} \\
(0.0121) \\
\end{array}$ & $\begin{array}{c}-0.0348^{* * *} \\
(0.0070) \\
\end{array}$ & $\begin{array}{c}0.1933^{* * *} \\
(0.0477) \\
\end{array}$ & $\begin{array}{c}0.2160^{* * *} \\
(0.0406) \\
\end{array}$ & $\begin{array}{c}-0.0294^{* * *} \\
(0.0075) \\
\end{array}$ & $\begin{array}{c}-0.0524^{* * *} \\
(0.0103) \\
\end{array}$ & $\begin{array}{c}-0.0157^{* * *} \\
(0.0040) \\
\end{array}$ & $\begin{array}{c}-0.0145^{* * *} \\
(0.0028) \\
\end{array}$ & $\begin{array}{c}-0.0264^{* * *} \\
(0.0066) \\
\end{array}$ & $\begin{array}{c}-0.0076^{* * *} \\
(0.0016) \\
\end{array}$ & $\begin{array}{c}-0.0135^{* * *} \\
(0.0035) \\
\end{array}$ & $\begin{array}{c}-0.0754^{* * *} \\
(0.0145) \\
\end{array}$ \\
\hline $\begin{array}{l}\text { Commerce, } \\
\text { business }\end{array}$ & $\begin{array}{c}-0.0202^{* * *} \\
(0.0053) \\
\end{array}$ & $\begin{array}{c}-0.0217^{* * * *} \\
(0.0046) \\
\end{array}$ & $\begin{array}{c}-0.0164^{* * *} \\
(0.0042) \\
\end{array}$ & $\begin{array}{c}-0.0242^{* * *} \\
(0.0050) \\
\end{array}$ & $\begin{array}{c}-0.0294^{* * *} \\
(0.0075) \\
\end{array}$ & $\begin{array}{c}-0.0524^{* * *} \\
(0.0103) \\
\end{array}$ & $\begin{array}{c}0.0847^{* * *} \\
(0.0215) \\
\end{array}$ & $\begin{array}{l}0.1659^{* * * *} \\
(0.0320) \\
\end{array}$ & $\begin{array}{c}-0.0053^{* * *} \\
(0.0014) \\
\end{array}$ & $\begin{array}{c}-0.0100^{* * *} \\
(0.0020) \\
\end{array}$ & $\begin{array}{c}-0.0089^{* * *} \\
(0.00230 \\
\end{array}$ & $\begin{array}{c}-0.0053^{* * *} \\
(0.0011) \\
\end{array}$ & $\begin{array}{c}-0.0046^{* * *} \\
(0.0012) \\
\end{array}$ & $\begin{array}{c}-0.0523^{* * *} \\
(0.0104) \\
\end{array}$ \\
\hline $\begin{array}{l}\text { Agric., bio. } \\
\text { sciences }\end{array}$ & $\begin{array}{c}-0.0108^{* * *} \\
(0.0028) \\
\end{array}$ & $\begin{array}{c}-0.0060^{* * *} \\
(0.0012) \\
\end{array}$ & $\begin{array}{c}-0.0087^{* * *} \\
(0.0022) \\
\end{array}$ & $\begin{array}{c}-0.0067^{* * *} \\
(0.0013) \\
\end{array}$ & $\begin{array}{l}-0.0157^{* * *} \\
(0.00400 \\
\end{array}$ & $\begin{array}{l}-0.0145^{* * *} \\
(0.0028) \\
\end{array}$ & $\begin{array}{c}-0.0053^{* * *} \\
(0.0014) \\
\end{array}$ & $\begin{array}{c}-0.0100^{* * *} \\
(0.0020) \\
\end{array}$ & $\begin{array}{c}0.0476^{* * *} \\
(0.0120)\end{array}$ & $\begin{array}{c}0.0531^{* * *} \\
(0.0100)\end{array}$ & $\begin{array}{c}-0.0047^{* * *} \\
(0.0012) \\
\end{array}$ & $\begin{array}{c}-0.0015^{* * *} \\
(0.0003) \\
\end{array}$ & $\begin{array}{c}-0.0024^{* * *} \\
(0.0006) \\
\end{array}$ & $\begin{array}{c}-0.0144^{* * *} \\
(0.0028) \\
\end{array}$ \\
\hline Health & $\begin{array}{c}-0.0181^{* * *} \\
(0.0046) \\
\end{array}$ & $\begin{array}{c}-0.0031^{* * *} \\
(0.0007) \\
\end{array}$ & $\begin{array}{c}-0.0147^{* * *} \\
(0.0037) \\
\end{array}$ & $\begin{array}{c}-0.0035^{* * *} \\
(0.0008) \\
\end{array}$ & $\begin{array}{c}-0.0264^{* * *} \\
(0.0066)\end{array}$ & $\begin{array}{c}-0.0076^{* * *} \\
(0.0016)\end{array}$ & $\begin{array}{c}-0.0089^{* * *} \\
(0.0023)\end{array}$ & $\begin{array}{c}-0.0053^{* * *} \\
(0.0011) \\
\end{array}$ & $\begin{array}{c}-0.0047^{* * *} \\
(0.0012) \\
\end{array}$ & $\begin{array}{c}-0.0015^{* * *} \\
(0.0003) \\
\end{array}$ & $\begin{array}{c}0.0769^{* * *} \\
(0.0191)\end{array}$ & $\begin{array}{l}0.0286^{* * *} \\
(0.0059)\end{array}$ & $\begin{array}{c}-0.0041^{* * *} \\
(0.0011) \\
\end{array}$ & $\begin{array}{c}-0.0076^{* * *} \\
(0.0016) \\
\end{array}$ \\
\hline Sciences & $\begin{array}{c}-0.0092^{* * *} \\
(0.0025) \\
\end{array}$ & $\begin{array}{c}-0.0312^{* * *} \\
(0.0065) \\
\end{array}$ & $\begin{array}{c}-0.0075^{* * *} \\
(0.0020)\end{array}$ & $\begin{array}{c}-0.0348^{* * *} \\
(0.0070) \\
\end{array}$ & $\begin{array}{c}-0.0135^{* * *} \\
(0.0035) \\
\end{array}$ & $\begin{array}{c}-0.0754^{* * *} \\
(0.0145) \\
\end{array}$ & $\begin{array}{c}-0.0046^{* * *} \\
(0.0012) \\
\end{array}$ & $\begin{array}{c}-0.0523^{* * *} \\
(0.0104) \\
\end{array}$ & $\begin{array}{c}-0.0024^{* * *} \\
(0.0006) \\
\end{array}$ & $\begin{array}{c}-0.0144^{* * *} \\
(0.0028) \\
\end{array}$ & $\begin{array}{c}-0.0041^{* * *} \\
(0.0011) \\
\end{array}$ & $\begin{array}{c}-0.0076^{* * *} \\
(0.00160 \\
\end{array}$ & $\begin{array}{c}0.0413^{* * *} \\
(0.0107)\end{array}$ & $\begin{array}{c}0.2158^{* * *} \\
(0.0407)\end{array}$ \\
\hline \multicolumn{15}{|c|}{ Earnings' rate of growth in: } \\
\hline Education & $\begin{array}{l}0.0061^{* * *} \\
(0.0014) \\
\end{array}$ & $\begin{array}{c}0.0024^{* * *} \\
(0.0009) \\
\end{array}$ & $\begin{array}{c}-0.0013^{* * *} \\
(0.0003) \\
\end{array}$ & $\begin{array}{c}-0.0003^{* *} \\
(0.0001) \\
\end{array}$ & $\begin{array}{c}-0.0024^{* * *} \\
(0.0006) \\
\end{array}$ & $\begin{array}{c}-0.0007^{* * *} \\
(0.0003) \\
\end{array}$ & $\begin{array}{c}-0.0008^{* * *} \\
(0.0002) \\
\end{array}$ & $\begin{array}{c}-0.0005^{* *} \\
(0.0002) \\
\end{array}$ & $\begin{array}{c}-0.0004^{* * *} \\
(0.0001) \\
\end{array}$ & $\begin{array}{c}-0.0001^{* * *} \\
(0.0001) \\
\end{array}$ & $\begin{array}{c}-0.0007^{* * *} \\
(0.0002) \\
\end{array}$ & $\begin{array}{c}-0.0001^{* *} \\
(0.0000) \\
\end{array}$ & $\begin{array}{c}-0.0004^{* * *} \\
(0.0001) \\
\end{array}$ & $\begin{array}{c}-0.0007^{* *} \\
(0.0003) \\
\end{array}$ \\
\hline $\begin{array}{l}\text { Fine arts, } \\
\text { humanities }\end{array}$ & $\begin{array}{c}-0.0013^{* * *} \\
(0.0003)\end{array}$ & $\begin{array}{c}-0.0003^{* *} \\
(0.0001) \\
\end{array}$ & $\begin{array}{c}0.0052^{* * *} \\
(0.0012) \\
\end{array}$ & $\begin{array}{c}0.0026^{* * *} \\
(0.0010) \\
\end{array}$ & $\begin{array}{c}-0.0020^{* * *} \\
(0.0005)\end{array}$ & $\begin{array}{c}-0.0008^{* * *} \\
(0.0003)\end{array}$ & $\begin{array}{c}-0.0007^{* * *} \\
(0.0002)\end{array}$ & $\begin{array}{c}-0.0005^{* * *} \\
(0.0002)\end{array}$ & $\begin{array}{c}-0.0004^{* * *} \\
(0.0001)\end{array}$ & $\begin{array}{c}-0.0001^{* * *} \\
(0.0001)\end{array}$ & $\begin{array}{c}-0.0006^{* * *} \\
(0.0001)\end{array}$ & $\begin{array}{c}-0.0001^{* *} \\
(0.0000) \\
\end{array}$ & $\begin{array}{c}-0.0003^{* * *} \\
(0.0001)\end{array}$ & $\begin{array}{c}-0.0008^{* * * *} \\
(0.0003)\end{array}$ \\
\hline $\begin{array}{l}\text { Social } \\
\text { Sciences }\end{array}$ & $\begin{array}{c}-0.0024^{* * *} \\
(0.0006)\end{array}$ & $\begin{array}{c}-0.0007^{* * *} \\
(0.0003)\end{array}$ & $\begin{array}{c}-0.0020^{* * * *} \\
(0.0005)\end{array}$ & $\begin{array}{c}-0.0008^{* * *} \\
(0.0003)\end{array}$ & $\begin{array}{c}0.0078^{* * *} \\
(0.0018)\end{array}$ & $\begin{array}{c}0.0048^{* * *} \\
(0.0018)\end{array}$ & $\begin{array}{c}-0.0012^{* * * *} \\
(0.0003)\end{array}$ & $\begin{array}{c}-0.0012^{* * *} \\
(0.0004) \\
\end{array}$ & $\begin{array}{c}-0.0006^{* * *} \\
(0.0002)\end{array}$ & $\begin{array}{c}-0.0003^{* * * *} \\
(0.0001)\end{array}$ & $\begin{array}{c}-0.0011^{* * *} \\
(0.0003)\end{array}$ & $\begin{array}{l}-0.0002^{* *} \\
(0.0001)\end{array}$ & $\begin{array}{c}-0.0005^{* * *} \\
(0.0001)\end{array}$ & $\begin{array}{c}-0.0017^{* * *} \\
(0.0006)\end{array}$ \\
\hline $\begin{array}{l}\text { Commerce, } \\
\text { business }\end{array}$ & $\begin{array}{c}-0.0008^{* * *} \\
(0.0002) \\
\end{array}$ & $\begin{array}{c}-0.0005^{* *} \\
(0.0002) \\
\end{array}$ & $\begin{array}{c}-0.0007^{* * *} \\
(0.0002) \\
\end{array}$ & $\begin{array}{c}-0.0005^{* * *} \\
(0.0002) \\
\end{array}$ & $\begin{array}{c}-0.0012^{* * *} \\
(0.0003) \\
\end{array}$ & $\begin{array}{c}-0.0012^{* * *} \\
(0.0004) \\
\end{array}$ & $\begin{array}{c}0.0034^{* * *} \\
(0.0008) \\
\end{array}$ & $\begin{array}{c}0.0037^{* * *} \\
(0.0014) \\
\end{array}$ & $\begin{array}{c}-0.0002^{* * *} \\
(0.0001) \\
\end{array}$ & $\begin{array}{c}-0.0002^{* * *} \\
(0.0001) \\
\end{array}$ & $\begin{array}{c}-0.0004^{* * *} \\
(0.0001) \\
\end{array}$ & $\begin{array}{c}-0.0001^{* *} \\
(0.0001) \\
\end{array}$ & $\begin{array}{c}-0.0002^{* * *} \\
(0.0000) \\
\end{array}$ & $\begin{array}{c}-0.0012^{* * *} \\
(0.0004) \\
\end{array}$ \\
\hline $\begin{array}{l}\text { Agric., bio. } \\
\text { sciences }\end{array}$ & $\begin{array}{c}-0.0004^{* * *} \\
(0.0001) \\
\end{array}$ & $\begin{array}{c}-0.0001^{* * *} \\
(0.0001) \\
\end{array}$ & $\begin{array}{c}-0.0004^{* * *} \\
(0.0001) \\
\end{array}$ & $\begin{array}{c}-0.0001^{* * *} \\
(0.0001) \\
\end{array}$ & $\begin{array}{c}-0.0006^{* * *} \\
(0.0002) \\
\end{array}$ & $\begin{array}{c}-0.0003^{* * *} \\
(0.0001) \\
\end{array}$ & $\begin{array}{c}-0.0002 * * * \\
(0.0001) \\
\end{array}$ & $\begin{array}{c}-0.0002 * * * \\
(0.0001) \\
\end{array}$ & $\begin{array}{c}0.0019^{* * *} \\
(0.0005)\end{array}$ & $\begin{array}{c}0.0012^{* * *} \\
(0.0004) \\
\end{array}$ & $\begin{array}{c}-0.0002^{* * *} \\
(0.0001) \\
\end{array}$ & $\begin{array}{c}0.0000^{* * *} \\
(0.0000) \\
\end{array}$ & $\begin{array}{c}-0.0001^{* * *} \\
(0.0000) \\
\end{array}$ & $\begin{array}{c}-0.0003^{* * * *} \\
(0.0001)\end{array}$ \\
\hline Health & $\begin{array}{c}-0.0007^{* * *} \\
(0.0002)\end{array}$ & $\begin{array}{c}-0.0001^{* *} \\
(0.0000) \\
\end{array}$ & $\begin{array}{c}-0.0006^{* * *} \\
(0.0001) \\
\end{array}$ & $\begin{array}{l}-0.0001^{* *} \\
(0.0000) \\
\end{array}$ & $\begin{array}{c}-0.0011^{* * *} \\
(0.0003)\end{array}$ & $\begin{array}{l}-0.0002^{* *} \\
(0.0001) \\
\end{array}$ & $\begin{array}{c}-0.0004^{* * *} \\
(0.0001)\end{array}$ & $\begin{array}{c}-0.0001^{* *} \\
(0.0001) \\
\end{array}$ & $\begin{array}{c}-0.0002^{* * *} \\
(0.0001)\end{array}$ & $\begin{array}{c}0.0000^{* * *} \\
(0.0000)\end{array}$ & $\begin{array}{c}0.0031^{\text {*** }} \\
(0.0007)\end{array}$ & $\begin{array}{l}0.0006^{* *} \\
(0.0003) \\
\end{array}$ & $\begin{array}{c}-0.0002^{* * *} \\
(0.0000) \\
\end{array}$ & $\begin{array}{c}-0.0002^{* *} \\
(0.0001) \\
\end{array}$ \\
\hline Sciences & $\begin{array}{c}-0.0004^{* * * *} \\
(0.0001) \\
\end{array}$ & $\begin{array}{l}-0.0007^{* *} \\
(0.0003) \\
\end{array}$ & $\begin{array}{c}-0.0003^{* * *} \\
(0.0001) \\
\end{array}$ & $\begin{array}{c}-0.0008^{* * *} \\
(0.0003) \\
\end{array}$ & $\begin{array}{c}-0.0005^{* * *} \\
(0.0001) \\
\end{array}$ & $\begin{array}{c}-0.0017^{* * *} \\
(0.0006) \\
\end{array}$ & $\begin{array}{c}-0.0002^{* * *} \\
(0.00000 \\
\end{array}$ & $\begin{array}{c}-0.0012^{* * *} \\
(0.0004) \\
\end{array}$ & $\begin{array}{c}-0.0001^{* * *} \\
(0.0000) \\
\end{array}$ & $\begin{array}{c}-0.0003^{* * * *} \\
(0.0001) \\
\end{array}$ & $\begin{array}{c}-0.0002^{* * *} \\
(0.0000) \\
\end{array}$ & $\begin{array}{c}-0.0002^{* * *} \\
(0.0001) \\
\end{array}$ & $\begin{array}{c}0.0017^{* * * *} \\
(0.0004) \\
\end{array}$ & $\begin{array}{c}0.0048^{* * *} \\
(0.0018)\end{array}$ \\
\hline
\end{tabular}

Note: In parentheses are standard-errors. $\left({ }^{*}\right),\left({ }^{* *}\right)$ and $\left({ }^{* *}\right)$ : significant at the level 10,5 and 1 percent (Two-tailed test). Marginal effects estimates for crossed variables are approximate. 
Table 6

Marginal Effects of the Remaining Covariates on the Probability of Choosing Each Field of Study

\begin{tabular}{|c|c|c|c|c|c|c|c|c|c|c|c|c|c|c|}
\hline & \multicolumn{2}{|c|}{ Education } & \multicolumn{2}{|c|}{$\begin{array}{c}\text { Fine arts. } \\
\text { humanities }\end{array}$} & \multicolumn{2}{|c|}{ Social sciences } & \multicolumn{2}{|c|}{$\begin{array}{c}\text { Commerce. } \\
\text { business }\end{array}$} & \multicolumn{2}{|c|}{$\begin{array}{c}\text { Agricultural, } \\
\text { biological sciences }\end{array}$} & \multicolumn{2}{|c|}{ Health } & \multicolumn{2}{|c|}{ Sciences } \\
\hline & Females & Males & Females & Males & Females & Males & Females & Males & Females & Males & Females & Males & Females & Males \\
\hline $\begin{array}{l}\text { Age at the beginning of } \\
\text { the program }\end{array}$ & $\begin{array}{l}0.0553^{* * *} \\
(0.0096) \\
\end{array}$ & $\begin{array}{l}0.0409^{* * *} \\
(0.0083)\end{array}$ & $\begin{array}{c}-0.0355^{* * *} \\
(0.0076)\end{array}$ & $\begin{array}{c}0.0108 \\
(0.0099)\end{array}$ & $\begin{array}{l}-0.0164 \\
(0.0112)\end{array}$ & $\begin{array}{c}-0.0017 \\
(0.01440\end{array}$ & $\begin{array}{l}-0.0119 \\
(0.0084)\end{array}$ & $\begin{array}{l}-0.0187 \\
(0.0125)\end{array}$ & $\begin{array}{c}-0.0150^{* * *} \\
(0.0039)\end{array}$ & $\begin{array}{c}-0.0218^{* * *} \\
(0.0044) \\
\end{array}$ & $\begin{array}{l}0.0279^{* * * *} \\
(0.00440\end{array}$ & $\begin{array}{c}0.0228^{* * *} \\
(0.0047)\end{array}$ & $\begin{array}{c}-0.0044 \\
(0.00390\end{array}$ & $\begin{array}{c}-0.0324^{* * *} \\
(0.0122)\end{array}$ \\
\hline Age squared & $\begin{array}{l}-0.0008^{* * * *} \\
(0.0002)\end{array}$ & $\begin{array}{l}-0.0005^{* * *} \\
(0.0001)\end{array}$ & $\begin{array}{l}0.0006^{* * *} \\
(0.0001)\end{array}$ & $\begin{array}{l}-0.0001 \\
(0.0002)\end{array}$ & $\begin{array}{l}0.0003^{*} \\
(0.0002)\end{array}$ & $\begin{array}{c}0.0001 \\
(0.0002)\end{array}$ & $\begin{array}{c}0.0001 \\
(0.00010\end{array}$ & $\begin{array}{c}0.0002 \\
(0.0002)\end{array}$ & $\begin{array}{l}0.0002^{* * *} \\
(0.0001)\end{array}$ & $\begin{array}{l}0.0003^{* * *} \\
(0.0001)\end{array}$ & $\begin{array}{l}-0.0004^{* * *} \\
(0.00010\end{array}$ & $\begin{array}{l}-0.0004^{* * *} \\
(0.00010\end{array}$ & $\begin{array}{c}0.0000 \\
(0.0001)\end{array}$ & $\begin{array}{l}0.0004^{* *} \\
(0.0002)\end{array}$ \\
\hline Cohort 1995 & $\begin{array}{c}0.0704^{* * *} \\
(0.0186)\end{array}$ & $\begin{array}{c}0.0766^{* * *} \\
(0.0164) \\
\end{array}$ & $\begin{array}{l}-0.0267 \\
(0.0185)\end{array}$ & $\begin{array}{l}0.0392^{* *} \\
(0.0195) \\
\end{array}$ & $\begin{array}{c}0.0290 \\
(0.0241) \\
\end{array}$ & $\begin{array}{l}-0.0141 \\
(0.0257) \\
\end{array}$ & $\begin{array}{l}-0.0446^{* * *} \\
(0.01560\end{array}$ & $\begin{array}{l}-0.0359 \\
(0.0224) \\
\end{array}$ & $\begin{array}{c}-0.0388^{* * *} \\
(0.0084) \\
\end{array}$ & $\begin{array}{c}-0.0301^{* * *} \\
(0.0091)\end{array}$ & $\begin{array}{c}0.0249^{* * *} \\
(0.0092) \\
\end{array}$ & $\begin{array}{l}0.0085^{*} \\
(0.0046) \\
\end{array}$ & $\begin{array}{l}-0.0143 \\
(0.0087) \\
\end{array}$ & $\begin{array}{l}-0.0442^{* *} \\
(0.0208) \\
\end{array}$ \\
\hline Single & $\begin{array}{l}-0.0790^{* * * *} \\
(0.0178)\end{array}$ & $\begin{array}{l}-0.0129 \\
(0.0140)\end{array}$ & $\begin{array}{l}0.0417^{* * *} \\
(0.0161)\end{array}$ & $\begin{array}{l}0.0506^{* * *} \\
(0.01470)\end{array}$ & $\begin{array}{l}0.0430^{* *} \\
(0.0209)\end{array}$ & $\begin{array}{c}0.0196 \\
(0.0229)\end{array}$ & $\begin{array}{c}0.0074 \\
(0.01270\end{array}$ & $\begin{array}{l}-0.0087 \\
(0.0198)\end{array}$ & $\begin{array}{l}0.0157^{* *} \\
(0.0063)\end{array}$ & $\begin{array}{c}0.0020 \\
(0.0071)\end{array}$ & $\begin{array}{l}-0.0301^{* * *} \\
(0.0088)\end{array}$ & $\begin{array}{c}-0.0127^{* * *} \\
(0.0048)\end{array}$ & $\begin{array}{c}0.0013 \\
(0.0057)\end{array}$ & $\begin{array}{l}-0.0379^{* *} \\
(0.0178)\end{array}$ \\
\hline $\begin{array}{l}\text { Mother w/ secondary } \\
\text { college diploma }\end{array}$ & $\begin{array}{l}-0.0068 \\
(0.0217)\end{array}$ & $\begin{array}{l}-0.0147 \\
(0.0169)\end{array}$ & $\begin{array}{l}-0.0123 \\
(0.0212)\end{array}$ & $\begin{array}{c}0.0053 \\
(0.0207) \\
\end{array}$ & $\begin{array}{c}0.0121 \\
(0.0253) \\
\end{array}$ & $\begin{array}{c}0.0038 \\
(0.0310) \\
\end{array}$ & $\begin{array}{l}-0.0024 \\
(0.0148)\end{array}$ & $\begin{array}{c}0.0019 \\
(0.0243)\end{array}$ & $\begin{array}{c}0.0064 \\
(0.0086)\end{array}$ & $\begin{array}{l}0.0230^{* * *} \\
(0.0085)\end{array}$ & $\begin{array}{c}0.0082 \\
(0.0100)\end{array}$ & $\begin{array}{l}-0.0007 \\
(0.0047)\end{array}$ & $\begin{array}{l}-0.0052 \\
(0.0085) \\
\end{array}$ & $\begin{array}{l}-0.0186 \\
(0.0219)\end{array}$ \\
\hline $\begin{array}{l}\text { Mother with university } \\
\text { education }\end{array}$ & $\begin{array}{l}-0.0526^{* *} \\
(0.0256)\end{array}$ & $\begin{array}{l}-0.0036 \\
(0.0234)\end{array}$ & $\begin{array}{c}0.0048 \\
(0.0256)\end{array}$ & $\begin{array}{l}-0.0195 \\
(0.0229)\end{array}$ & $\begin{array}{c}0.0284 \\
(0.0318)\end{array}$ & $\begin{array}{l}-0.0188 \\
(0.0353)\end{array}$ & $\begin{array}{l}-0.0190 \\
(0.01670\end{array}$ & $\begin{array}{c}0.0457 \\
(0.0343)\end{array}$ & $\begin{array}{l}-0.0008 \\
(0.0096)\end{array}$ & $\begin{array}{l}0.0331^{* *} \\
(0.0137)\end{array}$ & $\begin{array}{l}0.0409^{* *} \\
(0.0179)\end{array}$ & $\begin{array}{c}0.0034 \\
(0.0063)\end{array}$ & $\begin{array}{l}-0.0016 \\
(0.0101)\end{array}$ & $\begin{array}{l}-0.0402 \\
(0.0272)\end{array}$ \\
\hline $\begin{array}{l}\text { Father with secondary } \\
\text { or college diploma }\end{array}$ & $\begin{array}{l}-0.0051 \\
(0.0219) \\
\end{array}$ & $\begin{array}{l}-0.0355^{* *} \\
(0.0150) \\
\end{array}$ & $\begin{array}{c}0.0166 \\
(0.0227) \\
\end{array}$ & $\begin{array}{l}-0.0220 \\
(0.0202) \\
\end{array}$ & & $\begin{array}{c}0.0217 \\
(0.0308) \\
\end{array}$ & $\begin{array}{c}0.0014 \\
(0.0152) \\
\end{array}$ & $\begin{array}{c}0.0355 \\
(0.0257) \\
\end{array}$ & $\begin{array}{c}0.0091 \\
(0.0087) \\
\end{array}$ & $\begin{array}{l}-0.0082 \\
(0.0082) \\
\end{array}$ & $\begin{array}{l}-0.0050 \\
(0.0098) \\
\end{array}$ & $\begin{array}{l}-0.0021 \\
(0.0052) \\
\end{array}$ & $\begin{array}{c}0.0137 \\
(0.0098) \\
\end{array}$ & $\begin{array}{c}0.0106 \\
(0.0220) \\
\end{array}$ \\
\hline $\begin{array}{l}\text { Father with university } \\
\text { education }\end{array}$ & $\begin{array}{c}0.0066 \\
(0.0254)\end{array}$ & $\begin{array}{l}-0.0415^{* *} \\
(0.0180)\end{array}$ & $\begin{array}{l}0.0462^{*} \\
(0.0253)\end{array}$ & $\begin{array}{c}0.0124 \\
(0.0229)\end{array}$ & $\begin{array}{l}-0.0549^{* *} \\
(0.0270)\end{array}$ & $\begin{array}{l}-0.0017 \\
(0.0314)\end{array}$ & $\begin{array}{l}-0.0227 \\
(0.0155)\end{array}$ & $\begin{array}{l}-0.0320 \\
(0.0271)\end{array}$ & $\begin{array}{l}0.0163^{*} \\
(0.0094)\end{array}$ & $\begin{array}{l}-0.0046 \\
(0.0088)\end{array}$ & $\begin{array}{l}-0.0074 \\
(0.0131)\end{array}$ & $\begin{array}{l}0.0244^{* * *} \\
(0.0071)\end{array}$ & $\begin{array}{c}0.0160 \\
(0.0107)\end{array}$ & $\begin{array}{c}0.0429 \\
(0.0266)\end{array}$ \\
\hline $\begin{array}{l}\text { Obtained a student } \\
\text { loan }\end{array}$ & $\begin{array}{c}0.0072 \\
(0.0168) \\
\end{array}$ & $\begin{array}{c}0.0148 \\
(0.0134) \\
\end{array}$ & $\begin{array}{l}-0.0127 \\
(0.0153)\end{array}$ & $\begin{array}{c}0.0001 \\
(0.0145)\end{array}$ & $\begin{array}{l}0.0356^{*} \\
(0.0204)\end{array}$ & $\begin{array}{l}-0.0031 \\
(0.0211) \\
\end{array}$ & $\begin{array}{c}-0.0345^{* * *} \\
(0.0119) \\
\end{array}$ & $\begin{array}{c}-0.0559^{* * *} \\
(0.0177) \\
\end{array}$ & $\begin{array}{l}0.0105^{*} \\
(0.0060)\end{array}$ & $\begin{array}{c}0.0220^{* * *} \\
(0.0068) \\
\end{array}$ & $\begin{array}{c}0.0035 \\
(0.0081) \\
\end{array}$ & $\begin{array}{c}0.0064 \\
(0.0040) \\
\end{array}$ & $\begin{array}{l}-0.0095^{*} \\
(0.0057) \\
\end{array}$ & $\begin{array}{c}0.0156 \\
(0.0161) \\
\end{array}$ \\
\hline Duration of studies & $\begin{array}{l}-0.0011^{* * *} \\
(0.0004)\end{array}$ & $\begin{array}{l}-0.0022^{* * *} \\
(0.0006)\end{array}$ & $\begin{array}{l}0.0007^{* * *} \\
(0.0002)\end{array}$ & $\begin{array}{l}0.0006^{*} \\
(0.0003)\end{array}$ & $\begin{array}{l}0.0006^{*} \\
(0.0003)\end{array}$ & $\begin{array}{l}-0.0012^{* *} \\
(0.0006)\end{array}$ & $\begin{array}{l}-0.0002 \\
(0.0002)\end{array}$ & $\begin{array}{l}-0.0004 \\
(0.0004)\end{array}$ & $\begin{array}{l}-0.0001 \\
(0.0001)\end{array}$ & $\begin{array}{l}-0.0001 \\
(0.0002)\end{array}$ & $\begin{array}{l}-0.0001 \\
(0.0001)\end{array}$ & $\begin{array}{l}0.0003^{* * *} \\
(0.0001)\end{array}$ & $\begin{array}{c}0.0002^{* * *} \\
(0.0001)\end{array}$ & $\begin{array}{l}0.0030^{* * *} \\
(0.0004)\end{array}$ \\
\hline Enrolled full-time & $\begin{array}{c}0.0568^{* * *} \\
(0.0216)\end{array}$ & $\begin{array}{c}0.0138 \\
(0.0146)\end{array}$ & $\begin{array}{l}-0.0197 \\
(0.0227) \\
\end{array}$ & $\begin{array}{l}-0.0231 \\
(0.0215)\end{array}$ & $\begin{array}{l}-0.0537^{*} \\
(0.0281)\end{array}$ & $\begin{array}{c}-0.1320^{* * *} \\
(0.0316) \\
\end{array}$ & $\begin{array}{l}-0.0423^{* *} \\
(0.0189)\end{array}$ & $\begin{array}{l}-0.0675^{* *} \\
(0.0282)\end{array}$ & $\begin{array}{c}0.0023 \\
(0.0089)\end{array}$ & $\begin{array}{c}0.0094 \\
(0.0094)\end{array}$ & $\begin{array}{l}0.0221^{* * *} \\
(0.0095)\end{array}$ & $\begin{array}{c}0.0352^{* * *} \\
(0.0042)\end{array}$ & $\begin{array}{c}0.0346^{* * *} \\
(0.0077)\end{array}$ & $\begin{array}{c}0.1641^{* * *} \\
(0.0178)\end{array}$ \\
\hline $\begin{array}{l}\text { Acquiring skills was } \\
\text { important }\end{array}$ & $\begin{array}{c}0.1575^{* * *} \\
(0.0193)\end{array}$ & $\begin{array}{l}0.0726^{* * *} \\
(0.0136)\end{array}$ & $\begin{array}{l}-0.1531^{* * *} \\
(0.0308)\end{array}$ & $\begin{array}{c}-0.1946^{* * *} \\
(0.0353)\end{array}$ & $\begin{array}{c}-0.1365^{* * *} \\
(0.0342)\end{array}$ & $\begin{array}{l}-0.0778^{* *} \\
(0.0368)\end{array}$ & $\begin{array}{c}0.0652^{* * *} \\
(0.0134)\end{array}$ & $\begin{array}{c}0.1041^{* * *} \\
(0.0208)\end{array}$ & $\begin{array}{c}0.0028 \\
(0.0097)\end{array}$ & $\begin{array}{l}-0.0154 \\
(0.0123)\end{array}$ & $\begin{array}{l}0.0558^{* * *} \\
(0.0089)\end{array}$ & $\begin{array}{c}0.0266^{* * *} \\
(0.0040)\end{array}$ & $\begin{array}{c}0.0084 \\
(0.0080)\end{array}$ & $\begin{array}{l}0.0845^{* * *} \\
(0.0231)\end{array}$ \\
\hline $\begin{array}{l}\text { Acquiring knowledge } \\
\text { was important }\end{array}$ & $\begin{array}{l}-0.0017 \\
(0.0440)\end{array}$ & $\begin{array}{l}0.0381^{*} \\
(0.0205)\end{array}$ & $\begin{array}{l}-0.0051 \\
(0.0336)\end{array}$ & $\begin{array}{c}0.0145 \\
(0.0236)\end{array}$ & $\begin{array}{c}0.0342 \\
(0.0390)\end{array}$ & $\begin{array}{c}-0.1367^{* * *} \\
(0.0450)\end{array}$ & $\begin{array}{l}-0.0746^{* *} \\
(0.03770\end{array}$ & $\begin{array}{c}0.0314 \\
(0.0320)\end{array}$ & $\begin{array}{c}0.0105 \\
(0.0111)\end{array}$ & $\begin{array}{l}0.0182^{* *} \\
(0.0087)\end{array}$ & $\begin{array}{l}0.0326^{* *} \\
(0.0160)\end{array}$ & $\begin{array}{l}0.0214^{* * *} \\
(0.0051)\end{array}$ & $\begin{array}{c}0.0040 \\
(0.0124)\end{array}$ & $\begin{array}{c}0.0131 \\
(0.0321)\end{array}$ \\
\hline $\begin{array}{l}\text { Getting high income } \\
\text { was important }\end{array}$ & $\begin{array}{c}0.0224 \\
(0.0317)\end{array}$ & $\begin{array}{l}-0.0141 \\
(0.0267)\end{array}$ & $\begin{array}{l}-0.0789^{* * * *} \\
(0.0269)\end{array}$ & $\begin{array}{l}-0.1479^{* * *} \\
(0.0327)\end{array}$ & $\begin{array}{c}0.0338 \\
(0.0343)\end{array}$ & $\begin{array}{c}0.0040 \\
(0.0378)\end{array}$ & $\begin{array}{l}0.0436^{* *} \\
(0.0185)\end{array}$ & $\begin{array}{l}0.0973^{* * *} \\
(0.0236)\end{array}$ & $\begin{array}{l}-0.0144 \\
(0.0127)\end{array}$ & $\begin{array}{l}-0.0189 \\
(0.0141)\end{array}$ & $\begin{array}{l}-0.0076 \\
(0.0132)\end{array}$ & $\begin{array}{l}-0.0086 \\
(0.0076)\end{array}$ & $\begin{array}{c}0.0011 \\
(0.0104)\end{array}$ & $\begin{array}{c}0.0882^{* * *} \\
(0.0240)\end{array}$ \\
\hline
\end{tabular}

Notes: In parentheses are standard-errors. $\left({ }^{*}\right),(* *)$ and $(* *)$ : significant at the level 10,5 and 1 percent (Two-tailed test). Covariates also include the province of

residence 12 months prior to starting university (coefficients not shown). Marginal effects are evaluated at the sample means for continuous variables, and the discrete

change in the probability between 0 and 1 for dummy variables. Marginal effects estimates for crossed variables are approximate. 